\title{
Pengetahuan, sikap Remaja Putri dan Dukungan Petugas Kesehatan terhadap Konsumsi Tablet Besi Folat SMKN 1 Bangsri Jepara:
}

\section{Sebuah Studi Cross Sectional}

\author{
Sari Tirthawati ${ }^{1}$, Ali Rosidi ${ }^{2 *}$, Enik Sulistyowati $^{3}, \operatorname{Rr}$ Annisa Ayuningtyas ${ }^{2)}$ \\ ${ }^{1}$ Seksi Kesga dan Gizi, Dinas Kesehatan Jepara \\ ${ }^{2}$ Program Studi Gizi Universitas Muhammadiyah Semarang \\ ${ }^{3}$ Jurusan Gizi Poltekkes Kemenkes Semarang \\ alirhesa@yahoo.co.id*
}

\begin{abstract}
The iron-folate tablets program on adolescent girls for anemia prevention still facing some obstacles, especially adherence to consuming them. This study aimed to determine the relationship between knowledge, attitudes, and health worker's support with the adherence of iron-folate tablets consumption.

This study was a cross-sectional study, conducted at SMKN 1 Bangsri Jepara. A number of 73 respondents were selected by stratified random sampling. The data were obtained through interviews using a questionnaire, and analyzed using Rank Spearman test.

The results showed that most respondents had moderate knowledge (54.8\%), good attitude (69.9\%), and good health worker's support (65.8\%). As much as $82.2 \%$ of adolescent girls did not comply to consume iron-folate tablet which were given once in a week. The unpleasant smell and taste of iron-folate was the reason for the respondent's $(31,5 \%)$ disiobedient. The statistical tests showed that there were relationships between knowledge and respondent's compliance $(p=0.004 ; r=0.334)$, attitude and respondent's compliance $(p=0.000 ; r=0.543)$ and health worker's support with the respondent's compliance $(p=0.000 ; r=0.544)$.

The health worker's support variable is the most dominant variable related to the compliance of iron-folate tablets consumption. It is shown that the higher the support from health workers, the higher the compliance of iron-folate tablets consumption.
\end{abstract}

Keywords: Compliance, adolescent girl, iron-folate tablet consumption

\section{PENDAHULUAN}

Anemia merupakan salah satu masalah kesehatan masyarakat di negara berkembang seperti Indonesia. Anemia banyak dialami oleh semua kelompok umur dan jenis kelamin terutama kaum remaja putri (Yunita et al, 2020 ; Alaofe et al, 2009 ; Sarada \& Thilak, 2016). Tingginya angka kejadian anemia pada remaja putri disebabkan pada fase ini terjadi pertumbuhan pesat yang diikuti dengan peningkatan kebutuhan zat besi. Berlawanan dengan tingginya kebutuhan, remaja putri justru sering menerapkan pola diet yang kurang tepat dengan alasan ingin 
menurunkan berat badan, seperti mengurangi asupan protein hewani yang mengandung zat besi sebagai bahan pembentukan hemoglobin darah. Selain pola diet, remaja putri dan WUS juga mengalami haid. Saat haid, kebutuhan zat besi meningkat dua kali lipat, terlebih jika ada gangguan haid berupa durasi haid yang lebih panjang dan volume darah haid yang lebih banyak (Adriani \& Wirjatmadi, 2012 ; Sulistyawati et al, 2019) Anemia pada remaja putri menyebabkan kondisi lemah dan lesu. Hal ini berdampak terhadap lemahnya kemampuan daya ingat sehingga prestasi akademik menjadi kurang optimal. Sebagai calon ibu yang akan hamil dan melahirkan bayi, kondisi anemia ini memperbesar risiko kematian ibu, bayi lahir prematur, dan berat bayi lahir rendah (BBLR) (Akmal, 2016 ; Andriani M. dan Wirjatmadi B, 2013). Data Riset Kesehatan Dasar (RISKESDAS) tahun 2018 menujukkan prevalensi anemia pada remaja putri meningkat. Jika pada tahun 2013 ditemukan sebesar 37,1 \% kasus anemia pada remaja putri, di tahun 2018 persentase kasus ini meningkat menjadi 48,9\%. Proporsi anemia terjadi paling besar di kelompok umur 15-24 tahun, dan 25-34 tahun.

Anemia pada remaja putri salah satunya disebabkan pengetahuan yang kurang mengenai anemia sehingga berakibat ketidakpatuhan konsumsi tablet besi folat pada remaja putri. Kepatuhan konsumsi tablet besi folat merupakan salah satu bentuk perilaku kesehatan. Perilaku kesehatan diawali dengan adanya niatan untuk mengonsumsi tablet tambah darah. Terdapat beberapa faktor yang memengaruhi terbentuknya niat seseorang, seperti sikap, norma subjektif, dan persepsi kontrol perilaku. Norma subjektif merupakan daya dukung untuk melakukan sebuah perilaku, yang didapat dari orangorang yang dianggap penting oleh individu yang bersangkutan, seperti keluarga, guru, atau atasan. Faktor penguat berkaitan dengan sikap dan perilaku petugas kesehatan, atau peraturan yang berkaitan dengan kesehatan, bahwa peran petugas kesehatan yang baik akan memberikan motivasi terhadap kepatuhan dalam mengkonsumsi tablet besi folat. Perubahan perilaku ketidakpatuhan mengonsumsi tablet besi folat menjadi perilaku kepatuhan dapat dilakukan melalui promosi kesehatan guna mencegah terjadinya Anemia yang berdampak pada kualitas sumber daya manusia. Hasil penelitian pada negara berkembang didapat bahwa satu faktor yang berhubungan dengan kepatuhan dalam mengkonsumsi tablet besi adalah pengetahuan mengenai tablet besi folat. Demikian pula penelitian di Palestina didapat hasil bahwa responden yang memiliki sikap dan motivasi yang baik, 
akan mengonsumsi tablet besi (Galloway el al, 2002 ; Amani, 2007 ; Seck \& Jackson,2008).

Tujuan penelitian ini adalah untuk menganalisis hubungan pengetahuan, sikap, dan dukungan petugas kesehatan dengan kepatuhan konsumsi tablet besi folat pada remaja putri di SMKN 1 Bangsri Jepara.

\section{METODE PENELITIAN}

Penelitian yang akan dilakukan ini adalah jenis penelitian observasional dengan pendekatan cross sectional, Penelitian ini dilaksanakan di SMK Negeri 1 Bangsri Kabupaten Jepara dengan alamat lokasi Jalan KH. Achmad Fauzan No. 17 Krasak, Bangsri, Jepara. Penelitian ini dilakukan pada bulan Januari-Maret 2019. Populasi pada penelitian ini adalah seluruh siswi SMKN 1 Bangsri Kabupaten Jepara. Sampel penelitian adalah siswi SMKN 1 bangsri, besar sampel ditentukan dengan menggunakan perhitungan rumus Slovin yaitu sejumlah 73 sampel, dengan menggunakan pengambilan sampel secara stratified random sampling. Variabel bebas dalam penelitian adalah pengetahuan, sikap, dan dukungan petugas kesehatan, sedangkan variabel terikat adalah kepatuhan konsumsi tablet besi folat. Data pengetahuan, sikap, dan dukungan petugas kesehatan, serta dukungan petugas kesehatan diperoleh dengan wawancara.
Analisis univariat dilakukan untuk mendeskripsikan semua variabel penelitian yang terdiri dari tingkat pengetahun, sikap , dukungan petugas kesehatan dan kepatuhan remaja putri dalam konsumsi tablet besi folat yang disajikan dalam tabel distribusi frekuensi. Sebelum dilakukan uji bivariat dilakukan uji kenormalan data dengan menggunakan uji Kolmogorov-Smirnov dan uji bivariat menggunakan Rank Spearman.

\section{HASIL DAN PEMBAHASAN}

\section{Umur Responden}

Gambaran umur responden berdasarkan umur pada remaja putri di SMKN 1 Bangsri ditunjukkan dengan jumlah responden dalam penelitian ini adalah 73 responden, dengan umur berkisar antara 15-16 tahun. Proporsi umur antara 15 tahun dengan 16 tahun sedikit lebih banyak umur 15 tahun sebesar 39 siswa $(53,4 \%)$. Sesuai dengan definisi WHO bahwa kelompok umur 10 - 18 tahun adalah kelompok remaja. Beberapa penelitian menunjukkan hasil bahwa kelompok yang rawan menderita anemia adalah remaja putri. Hal inilah yang mendasari dibentuknya program penanggulangan anemia gizi pada remaja putri (SMP, SMA, SMK dan sederajat) serta Wanita Usia Subur (WUS). Program ini digagas sebagai upaya strategis untuk memutus rata mantai anemia sebagai suatu masalah gizi. 
Tingginya angka kejadian anemia pada remaja putri dibandingkan remaja pria disebabkan kebutuhan zat besi pada remaja putri lebih banyak, terutama pada saat menstruasi (Triwinarni et al, 2017). Konsumsi tablet tambah darah dengan kandungan zat besi dan asam folat dipilih menjadi salah satu upaya pencegahan dan penanggulangan anemia pada kelompok usia ini. Upaya suplementasi tablet besi folat sudah diatur dalam buku Pedoman Pencegahan dan Penanggulangan Anemia Pada Remaja Putri dan Wanita Usia Subur (WUS). Kegiatan suplementasi tablet besi folat, sesuai panduan yang tertulis dalam buku pedoman tersebut, dilakukan secara mandiri dengan dosis 1 tablet seminggu sekali selama 16 minggu. Konsumsi ditingkatkan menjadi satu tablet setiap hari jika remaja putri sedang mengalami menstruasi. Program ini, meskipun sudah diatur dalam pedoman yang cukup jelas, pada pelaksanaannya masih mengalami banyak kendala terutama dalam hal kepatuhan (Kemenkes, 2018).

\section{Pengetahuan Anemia Responden di SMKN 1 Bangsri.}

Aspek tentang pengetahuan anemia meliputi 15 pertanyaan. Proporsi pertanyaan yang paling banyak di jawab benar oleh responden adalah gejala anemia dan manfaat tablet besi folat yaitu sebesar $100 \%$ dan pertanyaan yang paling sedikit dijawab benar oleh responden adalah sumber makanan zat besi penambah darah yang berasal dari nabati yaitu sebesar $52,05 \%$. Tabel 1. menunjukkan distribusi responden menurut jawaban pertanyaan tentang anemia di SMKN 1 Bangsri.

Tabel 1. Distribusi Responden Menurut Jawaban Pertanyaan Tentang Anemia di SMKN 1 Bangsri

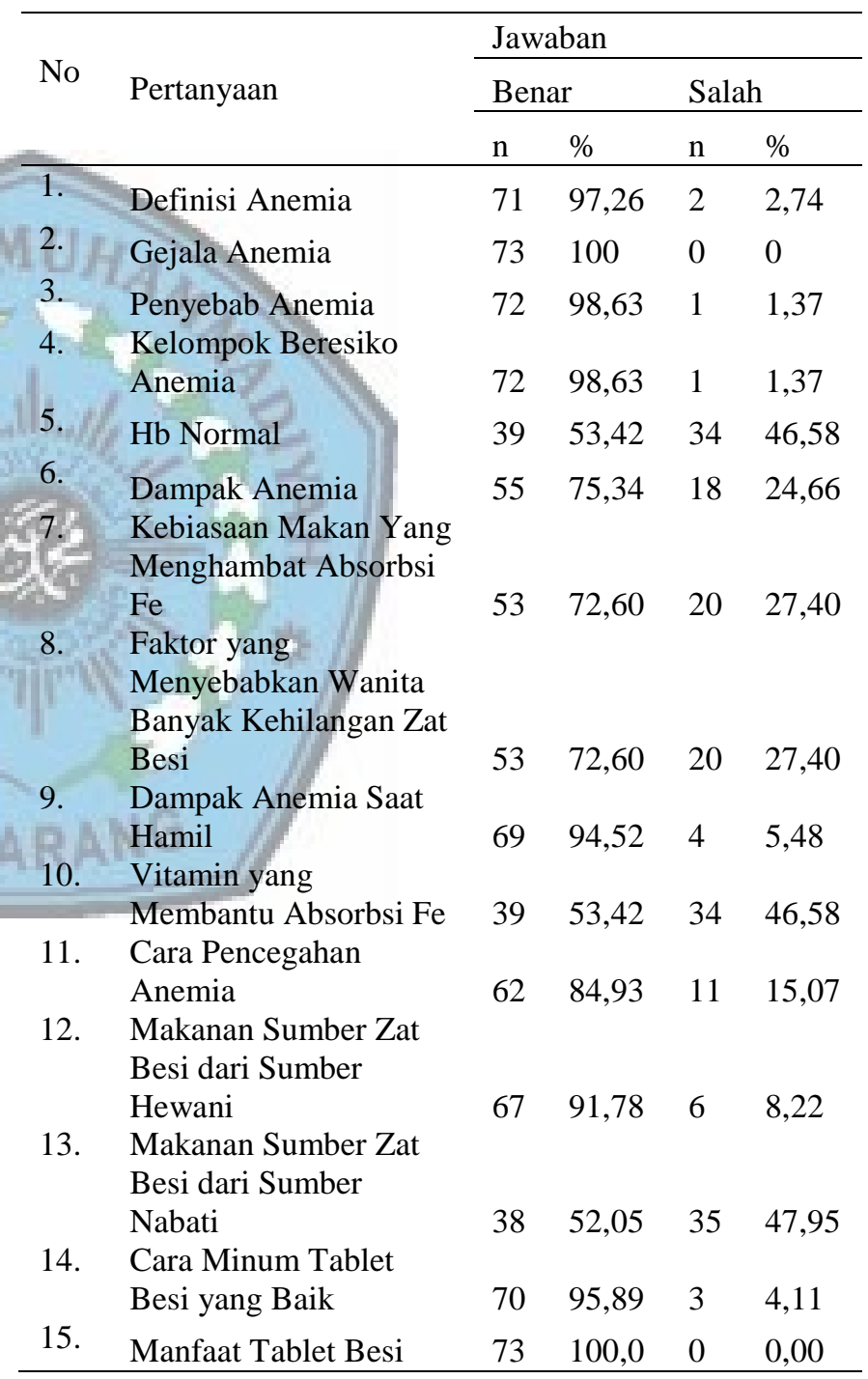


Tabel 2. Distribusi Frekuensi Responden berdasarkan Pengetahuan Tentang Anemia pada SMKN 1 Bangsri

\begin{tabular}{lll}
\hline Pengetahuan & n & \% \\
\hline Baik $(>80 \%)$ & 33 & $45.2 \%$ \\
Sedang $(60 \%-80 \%)$ & 40 & $54.8 \%$ \\
Kurang $(<60 \%)$ & 0 & $0 \%$ \\
\hline Jumlah & $\mathbf{7 3}$ & $\mathbf{1 0 0} \%$ \\
\hline
\end{tabular}

Tabel 1 menunjukkan bahwa sebagian besar responden sudah mengetahui definisi anemia, gejala anemia, penyebab anemia, kelompok yang beresiko anemia, dampak anemia dan manfaat tablet besi folat untuk pencegahan anemia. Meskipun demikian, masih terdapat responden yang menganggap penyakit anemia sama dengan darah rendah sehingga tidak berani mengonsumsi tablet besi folat karena takut akan menjadi darah tinggi.

Berdasarkan Pengkategorian Khomsan (2000) didapatkan hasil bahwa proporsi yang paling banyak pada kategori pengetahuan sedang sebesar 40 responden $(54,8 \%)$ dan tidak ditemukan responden yang mempunyai pengetahuan kurang. Adapun gambaran proporsi pengetahuan tentang anemia pada SMKN 1 Bangsri dapat dilihat pada Tabel 2. Pengetahuan sesorang didapat dari proses "tahu", dan dipengaruhi oleh informasi dan pengalaman. Seseorang dengan sumber informasi yang lebih banyak berpotensi memiliki pengetahuan yang lebih luas. Sumber informasi ini dapat diperoleh baik dari pendidikan formal maupun non formal. Pengalaman terhadap suatu kejadian dapat pula menambah pengetahuan seseorang tentang sesuatu yang bersifat informal. Lingkungan dapat pula memengaruhi pengetahuan seseorang dan berperan terhadap pembentukan sikap dan perilaku remaja putri (Mubarak, 2007 ; Notoadmodjo, 2010 ; Kalogianni, 2011). Pemberian informasi untuk meningkatkan pengetahuan remaja putri di SMKN 1 Bangsri diberikan pada saat Masa Orientansi Siswa (MOS) pada awal tahun ajaran baru oleh petugas kesehatan dari Puskesmas Bangsri I. 
Sikap tentang Anemia Responden di SMKN 1 Bangsri

Tabel 3. Distribusi Responden Menurut Jawaban Pernyataan Sikap Positif dan Negatif Tentang Anemia di SMKN 1 Bangsri

\begin{tabular}{|c|c|c|c|c|c|c|c|}
\hline \multirow{3}{*}{ Pernyataan Positif } & \multicolumn{7}{|c|}{ Jawaban } \\
\hline & \multicolumn{2}{|c|}{ Setuju } & \multicolumn{2}{|c|}{ Ragu Ragu T } & \multicolumn{3}{|c|}{ Tidak Setuju } \\
\hline & $\mathrm{n}$ & $\%$ & $\mathrm{n}$ & $\%$ & $\mathrm{n}$ & \multicolumn{2}{|c|}{$\frac{\mathrm{K} \text { Setuju }}{\%}$} \\
\hline Bahaya Anemia & 61 & 83,56 & 12 & 16,44 & 0 & \multicolumn{2}{|l|}{0} \\
\hline Pencegahan Anemia & 68 & 93,15 & 5 & 6,85 & 0 & \multicolumn{2}{|l|}{0} \\
\hline Perlunya Makanan Sumber Zat Besi & 67 & 91,78 & 6 & 8,22 & 0 & \multicolumn{2}{|l|}{0} \\
\hline Perlunya Minum Tablet Besi & 35 & 47,95 & 30 & 41,10 & 8 & \multicolumn{2}{|c|}{10,9} \\
\hline Frekuensi Minum Tablet Besi & 44 & 60,27 & 29 & 39,73 & 0 & \multicolumn{2}{|c|}{0} \\
\hline Dampak Anemia Saat ini & 66 & 90,41 & 7 & 9,59 & 0 & \multicolumn{2}{|l|}{0} \\
\hline Dampak Anemia Ketika Hamil & 47 & 64,38 & 25 & 34,25 & 1 & \multicolumn{2}{|c|}{1,37} \\
\hline Dampak Anemia Ketika Melahi & 49 & 67,12 & 23 & 31,51 & 1 & \multicolumn{2}{|c|}{1,37} \\
\hline \multirow[t]{2}{*}{ Pernyataan Negatif } & & C & $\mathrm{D}$ & gu Ragu & & \multicolumn{2}{|c|}{ Setuju } \\
\hline & II & & $\mathrm{n}$ & $\%$ & & $\mathrm{n}$ & $\%$ \\
\hline Bahaya Anemia & 59 & 80,8 & 10 & 13,70 & & 4 & 5,48 \\
\hline Dampak Anemia & $\begin{array}{r}43 \\
59\end{array}$ & $\begin{array}{l}58,9 \\
808\end{array}$ & $\begin{array}{lll}0 & 25 \\
2 & 1\end{array}$ & $\begin{array}{l}34,25 \\
1,37\end{array}$ & & $\begin{array}{l}5 \\
13\end{array}$ & $\begin{array}{l}6,85 \\
1781\end{array}$ \\
\hline Cara Minum Tablet Besi Yang B & 66 & 90,4 & 2 & 2,74 & & 5 & 6,85 \\
\hline Efek Samping Minum Tablet Fe & 40 & 54,7 & 11 & 15,07 & & 22 & 30,14 \\
\hline Pencegahan Anemia & 43 & 58,9 & 25 & 34,25 & & 5 & 6,85 \\
\hline Perlunya Konsumsi Sumber Zat & 67 & 91,7 & 6 & 8,22 & & 0 & 0 \\
\hline Pengaruh Absorbsi Zat Besi & 39 & 53,4 & 32 & 43,84 & & 2 & 2,74 \\
\hline
\end{tabular}

Aspek sikap responden tentang anemia meliputi 16 pernyataan, yang terdiri dari pernyataan positif dan pernyataan negatif. Pernyataan positif sebanyak 8 pernyataan dan pernyataan negatif terdiri dari 8 pernyataan. Proporsi pernyataan positif yang paling banyak di jawab setuju oleh responden adalah pernyataan tentang pencegahan anemia yaitu sebesar 93,15\% dan pernyataan positif yang paling sedikit dijawab setuju oleh responden adalah perlunya minum tablet besi yaitu sebesar $47,95 \%$. 
Proporsi pernyataan negatif yang paling banyak di jawab tidak setuju oleh responden adalah pernyataan tentang perlunya konsumsi sumber zat besi sebesar $91,78 \%$ dan pernyataan negatif yang paling sedikit dijawab tidak setuju oleh responden adalah pengaruh minum teh terhadap absorbsi zat besi yaitu sebesar 53,42\%. Sikap responden dikategorikan menurut Azwar (2008) yaitu sikap baik dan sikap kurang baik. Pada Tabel 3 dapat terlihat bahwa distribusi responden berdasarkan sikap tentang anemia di SMKN 1 Bangsri diperoleh hasil bahwa sikap responden yang mempunyai kategori sikap baik adalah sebesar $69,9 \%$.

\section{Hasil penelitian menunjukkan} 69,9\% remaja putri di SMKN 1 Bangsri memiliki sikap yang baik. Sikap merupakan bentuk respon tertutup seseorang terhadap objek tertentu yang dapat menggambarkan suka atau tidak suka dan setuju atau tidak setuju. Sikap seseorang terhadap suatu objek dapat menjadi indikator seberapa banyak pengetahuan individu tersebut terhadap objek yang bersangkutan.Sikap terbentuk dari pengetahuan dan pengalaman, baik pengalaman pribadi maupun orang lain yang dianggap penting oleh individu tersebut. Semakin baik pengetahuan maka akan semakin positif sikap yang terbentuk (Notoadmodjo, 2010 ; Kalogianni, 2011; Rahmawati \& Subagio, 2012 ; Budiarni \&, Subagio, 2012)

Tabel 4. Distribusi $\quad$ Frekuensi Responden berdasarkan Sikap Tentang Anemia di SMKN 1 Bangsri

\begin{tabular}{lll}
\hline Sikap & n & \% \\
\hline Baik $(>42,78)$ & 51 & $69,9 \%$ \\
Kurang Baik $(<42,78)$ & 22 & $30,1 \%$ \\
\hline Jumlah & $\mathbf{7 3}$ & $\mathbf{1 0 0} \%$ \\
\hline
\end{tabular}

Dukungan Petugas Kesehatan Terhadap Anemia di SMKN 1 Bangsri Aspek mengenai penilaian responden terhadap dukungan petugas kesehatan tentang anemia meliputi 4 pertanyaan. Proporsi pertanyaan yang paling banyak di jawab "ya" oleh responden adalah anjuran minum tablet besi 1 minggu sekali, yaitu sebesar 97,26\% dan pertanyaan yang paling sedikit dijawab "ya" oleh responden adalah informasi tentang tablet besi yaitu $90,41 \%$.

Dukungan petugas kesehatan pada penelitian ini dikategorikan menjadi dua yaitu baik dan kurang. Pada Tabel 5 dapat dilihat bahwa berdasarkan hasil penelitian menunjukkan petugas kesehatan yang mempunyai dukungan baik terhadap 
anemia dan konsumsi tablet besi folat yaitu sebanyak 48 responden $(65,8 \%)$.

Tabel 5. Distribusi Responden Berdasarkan Dukungan Petugas Kesehatan Tentang Anemia di SMKN 1 Bangsri.

\begin{tabular}{lll}
\hline Dukungan & n & \% \\
\hline Baik $(>50 \%)$ & 48 & $65.8 \%$ \\
Kurang baik $(\leq 50 \%)$ & 25 & $34.2 \%$ \\
\hline Jumlah & 73 & $100 \%$
\end{tabular}

Pada penelitian ini responden di SMKN 1 Bangsri sebagian besar memberikan pernyataan adanya dukungan yang baik dari petugas kesehatan, artinya bahwa petugas kesehatan telah memberikan informasi terkait dengan penanggulangan anemia dan pentingnya konsumsi tablet besi folat. Dukungan petugas dalam bentuk pemberian informasi kepada siswi di SMKN 1 Bangsri dilaksanakan pada saat awal tahun ajaran baru yaitu pada saat Masa Orientasi Siswa (MOS) dan pada saat pertemuan evaluasi penanggulangan anemia tingkat puskesmas yang dilaksanakan pada akhir tahun. Faktor pendorong atau penguat menentukan apakah perilaku kesehatan memperoleh dukungan atau tidak. Sumber penguat dapat berasal dari petugas kesehatan sebagai kelompok referensi bagi masyarakat. Disamping itu ketersediaan fasilitas, sikap dan perilaku petugas kesehatan terhadap kesehatan juga akan mendorong terbentuknya perilaku. (Notoadmodjo, 2010 ; Kalogianni, 2011; Rahmawati \& Subagio, 2012 ; Budiarni \&, Subagio, 2012)

\section{Kepatuhan Responden Dalam Konsumsi Tablet Besi Folat}

Aspek kepatuhan konsumsi tablet besi folat meliputi 4 pertanyaan. Proporsi pertanyaan yang paling banyak di jawab "ya" oleh responden adalah bahwa tablet besi folat rutin dibagikan setiap minggu, sebesar $100 \%$. Pertanyaan tentang apakah tablet tambah darah yang didapatkan selalu diminum dijawab "tidak" oleh responden sebesar $82,2 \%$.

Tabel 6. Distribusi Responden Menurut Kepatuhan Konsumsi Tablet Besi Folat di SMKN 1 Bangsri

\begin{tabular}{|c|c|c|c|c|}
\hline \multirow{3}{*}{ Pertanyaan } & \multicolumn{4}{|c|}{ Jawaban } \\
\hline & \multicolumn{2}{|c|}{ Ya } & \multicolumn{2}{|c|}{ Tidak } \\
\hline & n & $\%$ & $\mathbf{n}$ & $\%$ \\
\hline $\begin{array}{lcc}\text { Apakah } & \text { Mendapat } & \text { Tablet } \\
\text { Tambah } & \text { Darah } & \text { Setiap } \\
\text { Minggu } & & \end{array}$ & 73 & 100 & 0 & 0 \\
\hline $\begin{array}{l}\text { Apakah Tablet Tambah } \\
\text { Darah Yang Di Dapatkan } \\
\text { Selalu Diminum }\end{array}$ & 13 & 17,8 & 60 & 82,2 \\
\hline
\end{tabular}

Kepatuhan mengonsumsi tablet zat besi diukur dari ketepatan jumlah tablet yang dikonsumsi per bulan, sesuai pedoman yang dikeluarkan oleh 
Kemenkes RI tahun 2018 adalah 1 tablet per minggu atau minimal 4 tablet perbulan. Kategori kepatuhan di ukur berdasarkan Nuradhiani (2017) yaitu kategori patuh jika tablet besi folat yang dikonsumsi dalam 1 bulan $>75 \%$ dan kategori tidak patuh jika tablet besi folat yang dikonsumsi $\leq 75 \%$. Dari hasil penelitian ini responden yang tidak patuh dalam konsumsi tablet besi folat yaitu 60 responden $(82,2 \%)$ dan responden yang patuh dalam konsumsi tablet besi folat adalah 13 responden $(17,8 \%)$. Proporsi responden yang tidak patuh dalam konsumsi tablet besi folat sama dengan penelitian Juwita (2018) pada ibu hamil di wilayah Kerja Puskesmas Sikijang kabupaten Pelalawan sebanyak 8 orang $(17,8 \%)$. Hasil penelitian ini lebih baik daripada hasil penelitian Wileyati \& Riyanto (2012) sebesar 96,4\% tidak patuh mengonsumsi tablet besi Folat.

Tabel 7. Distribusi Responden

Berdasarkan Kepatuhan Konsumsi

Tablet Besi Folat Pada Remaja Putri di SMK Negeri 1 Bangsri

\begin{tabular}{lll}
\hline Kepatuhan & $\mathbf{n}$ & $\mathbf{\%}$ \\
\hline Patuh $(>75 \%)$ & 13 & $17.8 \%$ \\
Tidak patuh $(\leq 75 \%)$ & 60 & $82.2 \%$ \\
\hline Jumlah & $\mathbf{7 3}$ & $\mathbf{1 0 0} \%$ \\
\hline
\end{tabular}

Dari hasil penelitian dapat diketahui alasan responden tidak patuh dalam konsumsi tablet besi folat yaitu 23 responden $(31,5 \%)$ remaja putri beralasan tablet besi folat mempunyai bau dan rasa yang tidak enak. Kepatuhan mengonsumsi tablet besi folat merupakan perilaku dimana remaja putri mendukung program suplementasi besi yang dilakukan oleh pemerintah untuk mencegah anemia pada remaja putri.

Pada penelitian ini guru sebagai penangungjawab dalam pengadaan dan pendistribusian tablet besi folat disekolah melalui pengambilan tablet besi folat di Puskesmas Bangsri I setiap satu minggu sekali. Hasil penelitian ini menunjukkan sebanyak 60 responden $(82,2 \%)$ remaja putri di SMKN 1 Bangsri tidak patuh dalam mengkonsumsi tablet besi folat. Menurut Sarafino (2006) bahwa ketidakpatuhan terhadap minum obat bervariasi sesuai tergantung pada tujuan pengobatan tersebut. Pengobatan kuratif atau preventif, pengobatan jangka pendek atau jangka panjang. Ketidakpatuhan terhadap obat sangat ditentukan oleh prosedur pengobatan yang komplek, perubahan hidup yang dibutuhkan, lama nasehat pada pasien, keparahan penyakit yang diderita, potensi obat untuk sembuh. Hasil penelitian ditemukan bahwa alasan 
yaitu sebagian besar remaja putri $(31,5 \%)$ tidak patuh mengonsumsi tablet besi folat adalah bau dan rasa yang tidak enak. Menurut Briawan et al (2009), program pelaksanaan pemberian tablet besi folat parameter keberhasilnyan adalah menurunnya prevalensi anemia pada kelompok remaja. Parameter yang dapat digunakan untuk menilai keberhasulan pada program kelompok remaja adalah perubahan status anemia dengan peningkatan kadar haemoglobin.

Hubungan Pengetahuan Responden Dengan Kepatuhan Konsumsi Tablet Besi Folat di SMKN 1 Bangsri.

Berdasarkan hasil uji bivariat ditemukan bahwa pengetahuan tentang anemia responden berhubungan dengan kepatuhan mengkonsumsi tablet besi folat ( $p=0,004, \mathrm{r}=0,334)$. Hal ini sesuai dengan penelitian Wahyuningsih dan Uswatun (2019) ada hubungan pengetahuan tentang anemia dengan kepatuhan mengkonsumsi tablet tambah darah remaja putri di SMA Negeri 1 Karanganom

Pengetahuan mempunyai pengaruh sebagai dorongan kepada remaja putri untuk mengubah perilaku menjadi lebih baik. Hal ini disebabkan pengetahuan menjadi alasan kuat individu dalam melakukan suatu tindakan. Pengetahuan menjadi domain yang berperan penting terhadap pembentukan perilaku. Kepatuhan merupakan salah satu bentuk perilaku. Pengetahuan yang diperoleh melalui penginderaan remaja putri terhadap informasi kesehatan akan berpengaruh terhadap perilaku remaja putri dalam mengkonsumsi tablet besi folat (Hapzah \& Yulita, 2012 ; Husna \& Fatmawati, 2015). Menurut Hasrul et al (2010) informasi dan pengetahuan merupakan komponen penting dalam kepatuhan mengonsumsi tablet besi folat pada remaja putri.

\section{Hubungan Sikap Responden Dengan} Kepatuhan Konsumsi Tablet Besi Folat di SMKN 1 Bangsri.

Hasil hasil uji statistic diperoleh ada hubungan sikap dengan kepatuhan mengkonsumsi tablet besi folat $(p=0,000$ $r=0,543)$. Hal ini sesuai dengan penelitian Risva (2016) bahwa sikap yang baik terbukti dapat menciptakan kepatuhan yang baik dalam mengkonsumsi tablet besi folat pada remaja putri. Menurut Mar'at (2006) bahwa sikap terbentuk berdasarkan kebutuhan dan informasi yang diterima. Semakin banyak informasi positif yang diterima akan berperan kepada terbentuknya sikap yang positif. Sikap 
remaja putri yang positif tentang manfaat dari konsumsi tablet besi folat akan memberikan suatu sikap untuk mau mengkonsumsi tablet besi folat secara teratur.

\section{Hubungan}

Dukungan

Petugas

Kesehatan

Dengan

Kepatuhan

\section{Konsumsi Tablet Besi Folat}

Berdasarkan hasil uji satatistik diperoleh bahwa ada hubungan dukungan petugas kesehatan dengan kepatuhan konsumsi tablet besi folat $(p=0,000 \mathrm{r}=$ 0,544). Hal ini sejalan dengan penelitian Handayani (2013) yang menyebutkan bahwa petugas kesehatan berperan terhadap kepatuhan ibu hamil dalam mengonsumsi tablet besi di Desa Sidomulyo, Sidokarto dan Sidoluhur, Kecamatan Godean, Kabupaten Sleman, Yogyakarta. Tenaga kesehatan memiliki peranan penting dalam membangun komunikasi dengan remaja putri terkait edukasi seputar anemia dan masalah kesehatan remaja. Keberhasilan komunikasi dan interaksi antara tenaga kesehatan dengan remaja ini dapat diartikan sebagai sebuah bentuk dukungan dari tenaga kesehatan untuk remaja putri. (Nikmah, H.S., 2011; Garcia-Campayo, 2000). Menurut Green \& Kreuter, 2005) Dukungan orang disekitanya sangat penting termasuk dukungan petugas kesehatan, orangtua dan guru adalah faktor penguat kepatuhan mengonsumsi tablet besi folat pada remaja putri (Green $\&$ Kreuter, 2005).

\section{KESIMPULAN}

Pengetahuan, sikap dan dukungan petugas kesehatan berkorelasi positif terhadap kepatuhan konsumsi tablet besi folat pada remaja puteri

\section{DAFTAR PUSTAKA}

Adriani, M., \& Wirjatmadi, B. 2012. Peran gizi dalam status kehidupan. Jakarta: Kencana Prenada Media Group.

Akmal L. 2016. Analisis faktor yang berhubungan dengan kejadian anemia gizi pada remaja putri di SMKN 1 Terbanggi Besar Lampung Tangah. Jurnal Kesehatan, 7(3):455-469.

Alaofe, H., Zee, J., Dossa, R., \& O’brien, H. (2009). Eff ect of a nutrition education program and diet modifi cation in Beninese adolescent girls suff ering from mild iron defi ciency anemia. Ecology of Food Nutrition, 48(1), 21-38. doi: $10.1080 / 03670240802293675$

Ali Khomsan. Teknik Pengukuran Pengetahuan. Bogor: Institut Pertanian Bogor; 2000. h.30-5

Amani WM. 2007. Iron deficiency anemia among pregnant women in Nablus District; prevalence, Journal of Nutrition College, Volume 1, Nomor 1, Tahun 2012, 
Halaman 106 knowledge, attitude and practices. Nablus: AnNajah National University. 2007.

Andriani. M dan Wirjatmadi B. 2013. Pengantar Gizi Masyarakat. Jakarta: Kencana Pranada Media Grup.

Briawan D, Adriyani A, Pusporini. Determinan Keberhasilan Program Suplementasi Zat Besi pada Siswi Sekolah. Jurnal Gizi Klinik Indonesia. 2009;6(2):7883.

Budiarni W, Subagio HW. 2012. Hubungan pengetahuan, sikap, dan motivasi dengan kepatuhan konsumsi tablet besi folat pada ibu hamil. JNC. 2012;1(1): 269 82.

Dinas Kesehatan Kabupaten Jepara.2017. Profil Kesehatan Kabupaten Jepara. Dinkes Kabupaten Jepara

Galloway R, Erin D, Leslie E, et al. 2002 Women's perceptions of iron deficiency and anemia prevention and control in eight developing countries. Social Science \& Medicine 2002; 55: 529-44.

Garcia-Campayo J, Sanz-Carrillo C 2000. The Use Of Alternative Madicines by Somatoform Disorder Patients in Spain. British Journal Genetic Practical.

Green LW, Kreuter MW. 2005. Health Program Planning: An Educational and Ecological Approach (4th ed.). Boston: McGraw-Hill.

Handayani L. 2013. Peran Petugas Kesehatan Dan Kepatuhan Ibu Hamil Mengkonsumsi Tablet Besi Kesmas, Vol.7, No.2, September 2013
Hapzah., \& Yulita, R. (2012). Hubungan Tingkat Pengetahuan dan Status Gizi terhadap Kejadian Anemia Remaja Putri pada Siswi Kelas III di SMAN 1 Tinambung Kabupaten Polewali Mandar. Media Gizi Pangan, XIII(1), 20 25

Hasrul, 2010. Langkah-Langkah Pengembangan Pembelajaran Multimedia Interaktif. . Jurnal MEDTEK, Volume 2, Nomor 1, April 2010

Husna, U \& Fatmawati, R. (2015). Tentang Anemia Dengan Pola Makan ( Relationship of Knowledge About Anemia on Young Women With Dietary ). Profesional Islam, 12(2), 52-57.

Juwita R. 2018. Hubungan Konseling Dan Dukungan Keluarga Terhadap Kepatuhan Ibu Hamil Mengkonsumsi Tablet Fe. Jurnal Endurance 3(1) Februari 2018 (112-120)

Kalogianni A. 2011. Factors affect in patient adherence to medication regimen. Health Science Journal. 2011; 5:157-8.

Kementerian Kesehatan Republik Indonesia. Riset kesehatan dasar (RISKESDAS) tahun 2013. Jakarta: Badan Penelitian dan Pengembangan Kesehatan Kementerian Kesehatan Republik Indonesia; 2013.

Kementerian Kesehatan Republik Indonesia. Riset kesehatan dasar (RISKESDAS) tahun 2018. Jakarta: Badan Penelitian dan Pengembangan Kesehatan Kementerian Kesehatan Republik Indonesia; 2018.

Khomsan A , 2007. Studi Peningkatan Pengetahuan Gizi Ibu dan Kader 
Serta Perbaikan Gizi Balita. Bogor. Departemen Gizi Masyarakat. Institut Pertanian Bogor.

Mar'at, 2006. Sikap Manusia, Perubahan Serta Pengukurannya. Jakarta. Ghalia

Mubarak. 2007. Promosi Kesehatan. Graha Ilmu. Yogyakarta.

Nikmah, H.S. 2011. Komunikasi Kesehatan. Jurnal Ilmu omunikasi, 1 (2), 170-93

Notoadmodjo, S. 2010. Prinsip-prinsip dasar ilmu kesehatan masyarakat. Jakarta: Rineka cipta

Nuradhiani A, Briawan D, Dwiriani CM. 2017. Dukungan Guru Meningkatkan Kepatuhan Konsumsi Tablet Tambah Darah Pada Remaja Putri Di Kota Bogor. J. Gizi Pangan, November 2017, 12(3):153-160 ISSN 19781059

Rahmawati F, Subagio HW. 2012. Compliance of iron folate tablets consumption in pregnant women at Puskesmas Halmahera and The factors influenced. JNC. 2012;1(1):111-24.

Risva CT. 2016. Faktor-Faktor Yang Berhubungan Dengan Kebiasaan Konsumsi Tablet Tambah Darah Sebagai Upaya Pencegahan Anemia Pada Remaja Puteri (Studi Pada Mahasiswa Tahun Pertama Di Fakultas Kesehatan Masyarakat Universitas Diponegoro). Jurnal Kesehatan Masyarakat (e-Journal) Volume 4, Nomor 3, April 2016 (ISSN: 2356-3346)

Riyanto, weliyati. 2012. Faktor terjadinya anemia pada remaja di SMA Negeri Kota Metro, Jurnal
Kesehatan Metro Sai Wawai Volume No 2 Edisi Desember 2013

Sarada A. K., Thilak S. A. 2016. Evaluation of weekly iron and folic acid supplementation programme for adolescents in rural schools of Kannur, North Kerala, India: a cross-sectional study. International Journal of Medical Science and Public Health. 2016;5(11):2259-2263. doi:

10.5455/ijmsph.2016.010420164 52

Sarafino. 2006. Health Psycology Biopsychosocial Interactions 5ed. John Wiley \& Sons Inc.USA.

Seck BC, Jackson RT. 2008. Determinants of compliance with iron supplementation among pregnant women in Senegal. Public Health Nutr. 2008; 11(6): 596- 605.

Sulistyawati, Margawati A, Rosidi A, Suhartono. 2019. Riwayat paparan pestisida dan kekurangan asupan zat gizi sebagai faktor risiko kejadian anemia pada ibu hamil di daerah pertanian. Jurnal Gizi Indonesia (The Indonesian Journal of Nutrition) Vol. 7, No. 2, Juni 2019 (69-75

Triwinarni, C., Hartini, T. N. S., \& Susilo, J. (2017). Hubungan status gizi dengan kejadian anemia gizi besi (AGB) pada siswi SMA di Kecamatan Pakem. Jurnal Nutrisia, 19(1), 61-67.

Wahyuningsih A, Uswatun A. 2019. Hubungan Pengetahuan Tentang Anemia Dengan Kepatuhan Mengkonsumsi Tablet Tambah Darah Remaja Putri Di Sma Negeri 1 Karanganom Jurnal 
Involusi Kebidanan Vol. 9 No. 17

, 4

Yunita FA, Parwatiningsih SA, Hardiningsih, Yuneta AEN, Kartikasari MND, Ropitasari. 2020. Hubungan Pengetahuan Remaja Putri Tentang Konsumsi Zat Besi Dengan Kejadian Anemia Di Smp 18 Surakarta, Placentum Jurnal Ilmiah Kesehatan Dan Aplikasinya, Vol.8(1) 2020

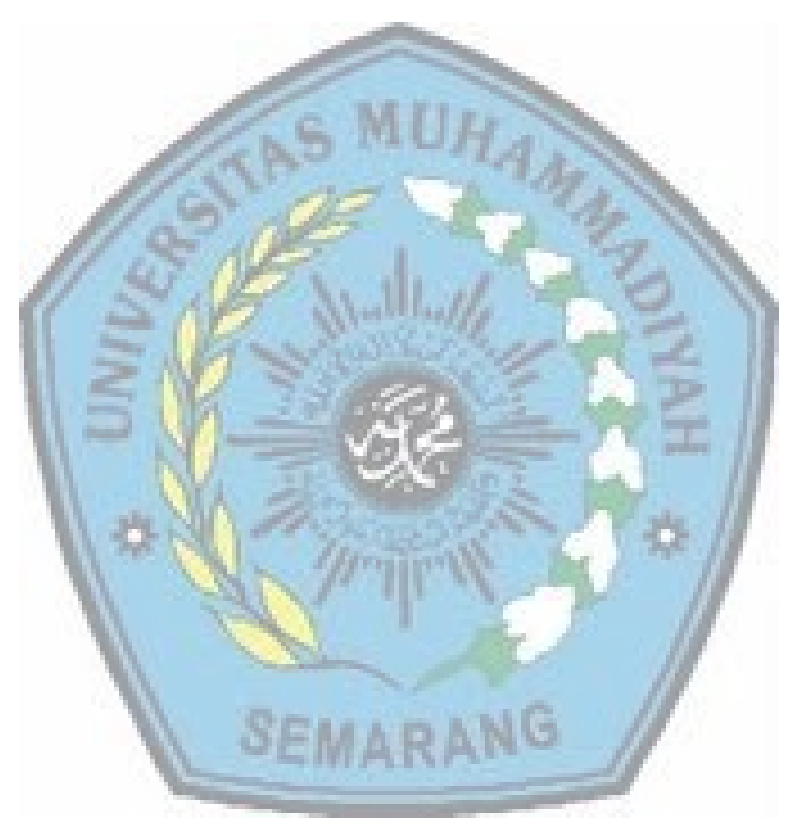

